\author{
I. KovalevsKa, O. Ruban, V. GRUdKo
}

National University of Pharmacy

\title{
STUDY OF BIOPHARMACEUTICAL SOLUBILITY OF QUERCETIN AND ITS SOLID DISPERSIONS
}

Topicality. Quercetin is a natural flavonoid, which has a variety of pharmacological properties, such as anti-inflammatory, antioxidant, anti-allergic, chemo-preventive, antiaggregate, etc. Despite the breadth of the pharmacological profile, its use is limited due to low solubility. Solid dispersions are widely used to increase the solubility of poorly soluble substances.

Aim. To determine the biopharmaceutical solubility of quercetin and its solid dispersions.

Materials and methods. The subjects of the study were the substance quercetin, its solid dispersion (SD) with macrogol-6000, which also included microcrystalline cellulose and neusilin. Samples of solid dispersions were obtained by liquid phase method. The ratio of AFI and carrier is as $1: 2$. Biopharmaceutical solubility of the samples was determined by the method of shaking the maximum single dose of quercetin $100 \mathrm{mg}$ at a constant temperature $\left(37 \pm 1{ }^{\circ} \mathrm{C}\right)$ for 24 hours in $250 \mathrm{ml}$ of buffer solutions with a physiological $\mathrm{pH}$ value $(1.2 ; 4.5 ; 6.8)$. Quantitative determination was carried out by spectrophotometric standard method. The statistical processing of the results of the experiment was carried out using the Microsoft Office Excel 2007 package.

Results and discussion. It was found that the adsorption spectra of quercetin solutions in buffer solutions with $\mathrm{pH}$ $1.2,4.5,6.8$ contain a wide inclined absorption band at a maximum of $365 \mathrm{~nm}$, which can be used to determine the concentration of quercetin solutions by the one-component single-wave spectrophotometry method according to the standard. It has been established that light absorption of quercetin solutions at $\lambda 365 \mathrm{~nm}$ is linear and obeys Beer-Lambert Law. It has been proved that macrogol-6000, used in the preparation of solid dispersions, does not affect the adsorption spectrum of quercetin solutions in buffer solutions with pHs of 1.2, 4.5, and 6.8. It was established that according to the solubility parameters in water buffer solutions with $\mathrm{pH}$ of $1.2,4.5$ and 6.8, quercetin refers to practically insoluble substances. Creating solid dispersions can increase the solubility ratios from 8 to 40 times depending on the $\mathrm{pH}$ of the buffer solution. The maximum solubility value is observed at $\mathrm{pH} 4.5$.

Conclusions. Thus, the use of solid dispersions significantly increases the value of quercetin biopharmaceutical solubility in a dose of $100 \mathrm{mg}$, and at a dose of $50 \mathrm{mg}$ it is close to normal when using $\mathrm{pH}$ of 4.5. The obtained results allow concluding that it is expedient to create enteric-soluble coated medicines.

Key words: biopharmaceutical solubility; quercetin; solid dispersion; spectrophotometric determination method

\section{І. В. Ковалевська, О. А. Рубан, В. О. Грудько}

\section{Вивчення біофармацевтичної розчинності кверцетину та його твердих дисперсій}

Актуальність. Кверцетин є природним флавоноїдом, який має різноманітні фармакологічні властивості, такі як протизапальні, антиоксидантні, протиалергічні, хіміопревентивні, антиагрегантні тощо. Незважаючи на широту фармакологічного профілю, його застосування обмежено низькою розчинністю. Для підвищення розчинності погано розчинних речовин широко застосовуються тверді дисперсії.

Мета. Таким чином, метою нашої роботи стало визначення біофармацевтичної розчинності кверцетину та його твердих дисперсій.

Матеріали та методи. Об’єктами дослідження були субстанція кверцетину, його тверда дисперсія (ТД) 3 макроголом-6000, до складу якої також входили мікрокристалічна целюлоза та неуселін. Зразки твердих дисперсій отримували рідиннофазним методом. Співвідношення АФІ та носія $1: 2$. Біофармацевтичну розчинність зразків визначали методом струшування максимальної разової дози кверцетину 100 мг при постійній температурі $\left(37 \pm 1^{\circ} \mathrm{C}\right)$ впродовж 24 годин у 250 мл буферних розчинів з фізіологічним значенням рН $(1,2 ; 4,5 ; 6,8)$. Кількісне визначення проводили спектрофотометричним методом стандарту. Статистичну обробку результатів експерименту здійснювали з використанням пакету Microsoft Office Excel 2007.

Результати та їх обговорення. Встановлено, що адсорбційні спектри розчинів кверцетину в буферних розчинах з $\mathrm{pH}$ 1,2, 4,5, 6,8 містять широкий похилий шар поглинання з максимумом при 365 нм, що може бути використаний для визначення концентрації розчинів кверцетину методом однокомпонентної однохвильової спектрофотометрії за стандартом. Встановлено, що світлопоглинання розчинів кверцетину при $\lambda 365$ нм носить лінійний характер і підпорядковується закону Бугера-Ламберта-Бера. Доведено, що макрогол-6000, використаний при одержанні твердих дисперсій, не впливає на адсорбційний спектр розчинів кверцетину в буферних розчинах з $\mathrm{pH} 1,2,4,5$, i 6,8. Встановлено, що за показниками розчинності у водних буферних розчинах $3 \mathrm{pH} 1,2$, 4,5 і 6,8 кверцетин відноситься до практично не розчинних речовин. Створення твердих дисперсій дозволяє збільшити показники розчинності від 8 до 40 разів залежно від рН буферного розчину. Максимальне значення розчинності спостерігається при $\mathrm{pH} 4,5$.

Висновки. Таким чином, застосування твердих дисперсій значно підвищує значення біофармацевтичної розчинності кверцетину у дозі 100 мг, а при застосуванні дози 50 мг наближається до норми при використанні середовища $\mathrm{pH}$ 4,5. Отримані результати дозволяють зробити висновок щодо доцільності створення лікарських засобів на основі кверцетину, покритих кишково-розчинною оболонкою.

Ключові слова: кверцетин; тверді дисперсії; біофармацевтична розчинність; спектрофотометричний метод 


\section{И. В. Ковалевская, Е. А. Рубан, В. А. Грудько \\ Изучение биофармацевтической растворимости кверцетина и его твердых дисперсий}

Актуальность. Кверцетин является естественным флавоноидом, который проявляет противовоспалительные, антиоксидантные, противоаллергические, химиопревентивные, антиагрегантные свойства. Несмотря на широту фармакологического профиля, его применение ограничено низкой растворимостью. Для повышения растворимости плохо растворимых веществ широко используется технология твердых дисперсий.

Цель работы. Таким образом, целью работы стало определение биофармацевтической растворимости кверцетина и его твердых дисперсий.

Материалы и методы. Объектами исследования были субстанция кверцетина, его твердая дисперсия (ТД) с макроголом-6000, микрокристаллической целлюлозой и неуселином. Образцы твердых дисперсий получали жидкофазным методом. Соотношение АФИ и носителя составляло $1: 2$, биофармацевтическую растворимость образцов определяли методом встряхивания максимальной разовой дозы кверцетина 100 мг при постоянной температуре $\left(37 \pm 1^{\circ} \mathrm{C}\right)$ в течение 24 часов в 250 мл буферного раствора с физиологическим значением рН $(1,2 ; 4,5 ; 6,8)$. Количественное определение проводили спектрофотометрическим методом стандарта. Статистическую обработку результатов эксперимента осуществляли с использованием пакета Microsoft Office Excel 2007.

Результаты и их обсуждение. Установлено, что адсорбционные спектры растворов кверцетина с рН 1,2, 4,5, 6,8 содержат широкую наклонную полосу поглощения с максимумом при 365 нм, которая может быть использована для определения концентрации методом однокомпонентной одноволновой спектрофотометрии по стандарту. Установлено, что светопоглощение растворов кверцетина при $\lambda 365$ нм носит линейный характер и подчиняется закону Бугера-Ламберта-Бера. Доказано, что макрогол-6000, который использовался при получении твердых дисперсий, не влияет на адсорбционный спектр растворов кверцетина в буферных растворах с $\mathrm{pH} 1,2,4,5$ и 6,8. Установлено, что по показателям растворимости в водных буферных растворах с $\mathrm{pH} 1,2,4,5$ и 6,8 кверцетин относится к практически не растворимым веществам. Создание твердых дисперсий позволяет увеличить показатели растворимости от 8 до 40 раз в зависимости от рН буферного раствора. Максимальное значение растворимости наблюдается при рН 4,5.

Выводы. Таким образом, применение твердых дисперсий значительно повышает значение биофармацевтической растворимости кверцетина в дозе 100 мг, а при применении в дозе 50 мг приближается к норме при использовании среды рН 4,5. Полученные результаты позволяют сделать вывод о целесообразности разработки лекарственных средств на основе кверцетина, покрытых кишечно-растворимой оболочкой.

Ключевые слова: кверцетин; твердые дисперсии; биофармацевтическая растворимость; спектрофотометрический метод

\section{INTRODUCTION}

Quercetin is a natural flavonoid, which has a variety of pharmacological properties, such as anti-inflammatory, antioxidant, anti-allergic, chemo-preventive, antiaggregate, etc. $[1,2]$. Despite the breadth of the pharmacological profile, its use is limited because of low solubility [3]. Today, there are many ways to increase solubility of active pharmaceutical ingredients (API) insoluble in the aqueous medium: micronization, obtaining of liposomes, nanoparticles, solid dispersions, and the like. Solid dispersions (SD) are used both to increase the solubility of poorly soluble substances, and to improve permeability by amorphizing, increasing the surface of particles, reducing their size. As a part of the solid dispersion, the wetting of active pharmaceutical ingredients (API) significantly changes, which affects the increase of interaction with the medium of dissolution [4].

As carriers, in the manufacture of solid dispersions, polymers are usually used. Previous studies have found that the rational carrier for quercetin in the solid dispersion is macrogol-6000. Macrogols or polyethylene oxides (PEO) are one of the most commonly used group of high molecular substances. PEOs are hydrophilic substances, do not exhibit toxic, irritating action, capable of increasing API wetting when it enters the aqueous medium. As a carrier for SD it is possible to use PEO with a molecular weight from 1500 to 20,000. Its melting temperature is about $60^{\circ} \mathrm{C}$., which is an advantage in obtai- ning SD by melting, especially when the API is thermally labile. Macrogols with higher molecular weight have a high viscosity, which slows down the process of substance release from the matrix of the carrier.

The aim is to determine the biopharmaceutical solubility of quercetin and its solid dispersions.

\section{MATERIALS AND METHODS}

The subjects of the study were the substance of quercetin, its solid dispersion (SD) with macrogol-6000, which also included microcrystalline cellulose and neusilin. Samples of solid dispersions were obtained by liquid phase method. The ratio of API and carrier was as $1: 2$.

Quercetin contains five hydroxyl groups (Fig. 1), which determine its high biological activity and permeability, but it is practically insoluble in an aqueous medium.

Biopharmaceutical solubility of the samples was determined by the method of shaking the maximum single dose of quercetin $100 \mathrm{mg}$ at a constant temperature $\left(37 \pm 1^{\circ} \mathrm{C}\right.$ ) for 24 hours in $250 \mathrm{ml}$ of buffer solutions with a physiological $\mathrm{pH}$ value $(1.2 ; 4.5 ; 6.8)$ prepared according to the technique, given in SPU 5.17.1 - "Manual for conducting the dissolution test" [5]. Quantitative determination was carried out by spectrophotometric standard method.

A solution of quercetin standard sample was prepared according to the following procedure: $0.0500 \mathrm{~g}$ of quercetin standard sample placed in a $100 \mathrm{ml}$ volumetric 


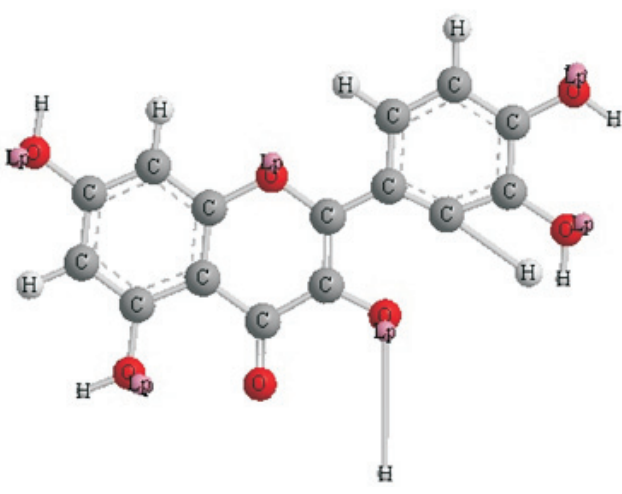

Fig. 1. Quercetin molecule

flask, $70 \mathrm{ml}$ of ethyl alcohol was added, stirred to dissolve and brought to the mark with solvent (solution 1 of quercetin SS). $2 \mathrm{ml}$ of solution $1 \mathrm{SS}$ of quercetin placed in a volumetric flask of $100 \mathrm{ml}$ capacity and added to the mark with buffer solutions of pH 1.2; 4.5 or 6.8 .

The adsorption spectra of quercetin solutions obtained were taken on Evolution 60-S spectrophotometer in dice with layer thickness of $10 \mathrm{~mm}$. As a control solution, an appropriate buffer solution ( $\mathrm{pH} 1.2 ; 4.5 ; 6.8)$ was used [5].

The amount of quercetin that passed into solution in grams was calculated by the formula 1 :

$$
S=\frac{A \cdot m_{S S} \cdot V_{2 S S}}{A_{S S} \cdot V_{1 S S} \cdot V_{3 S S}},
$$

where: $A$ - optical density of the investigated solution; $\mathrm{A}_{\mathrm{SS}}$ - optical density of the comparison solution; $m_{S S}$ - weight of quercetin SS (standard sample), $\mathrm{mg} ; V_{1 S S}$ is the volume of the volumetric flask for the first dilution of quercetin SS (100 ml); $V_{2 S S}$ - volume of aliquot of quercetin SS; $V_{3 S S}$ the volume of the volumetric flask for second dilution ( $25 \mathrm{ml}$ ).

Specific absorption rate of solutions was calculated by the formula 2 :

$$
A_{1 s m}^{1 \%}=\frac{A}{c b},
$$

where: $A$ is the optical density of the investigated solution; $c$ - concentration of solution $\mathrm{g} / 100 \mathrm{ml} ; b$ - the thickness of the layer in centimetres.

The ratio of the dose to the solubility was determined by formula 3 :

$$
S_{i}=\frac{D}{S}
$$

where: $D$ - dose of API, authorized for medical use; $S$ solubility, $\mathrm{mg} / \mathrm{ml}$.

The dose number indicates the amount of API that dissolves in $250 \mathrm{ml}$ of purified water. This indicator was calculated by the formula 4 :

$$
D_{0}=\frac{D}{S V_{0}}
$$

where: $S$ - solubility, $\mathrm{mg} / \mathrm{ml} ; V_{0}$ - volume of liquid with which the dose of API $(250 \mathrm{ml})$ is washed down .
The solubility index is considered to be high if the amount of the substance passed to the solution is within the range of $85-100 \%$, the dose number is $250.0-225.0$, the ratio of the dose to the solubility is close to 1 [7].

The statistical processing of the results of the experiment was carried out using the Microsoft Office Excel 2007 package by calculating the average value of the amount of substance dissolved and the relative standard deviation.

\section{RESULTS AND DISCUSSION}

The first stage of the experiment was to study the spectral characteristics of quercetin and to establish an analytical band of absorption. Absorption spectra of quercetin solutions in appropriate buffer solutions were taken on Evolution $60 \mathrm{~S}$ spectrophotometer in cells with a thickness of $10 \mathrm{~mm}$ in the region of 220 to $450 \mathrm{~nm}$. The obtained results are presented in Fig. 2.

The adsorption spectrum of the test solution of quercetin SS in a buffer solution at pH 1.2 is characterized by a pronounced narrow absorption band with a maximum at $252-254 \mathrm{~nm}$, which is characteristic for the absorption of aromatic compounds, including flavonoids. In the region 292-302 nm, an absorption band is located, which manifests itself in the form of an indistinct low-intensity plateau, and a wide, sloping, intense long-wave absorption band with a maximum at $365 \mathrm{~nm}$ is observed on the boundary of visible light, characteristic of flavonoids. This band is sufficiently specific, meets all the requirements for analytical absorption bands, and can be used to quantify quercetin in solution provided that there is no influence of other components of the solution on its total spectrum.

The adsorption spectrum of the test solution of quercetin SS in a buffer solution with pH 4.5 is very similar to the absorption spectrum at $\mathrm{pH}$ 1.2. It has the same maximum at 252-254 nm with a slightly more distinct band in the region of 290-293 $\mathrm{nm}$ and a broad intensive longwave band with a maximum at $365 \mathrm{~nm}$, which can also be an analytical band of absorption.

The adsorption spectrum of the quercetin SS test solution in a buffer solution at $\mathrm{pH} 6.8$ is similar to the previous absorption spectra, but all three maxima, although located in the same regions, are less pronounced.

Thus, in the spectra of quercetin solutions in buffer solutions with pHs of 1.2, 4.5 and 6.8 there is the same specific long-wave band with a rather flat broad highintensity maximum at $365 \mathrm{~nm}$, which can be used as an analytical absorption band for determining the concentration of quercetin solutions in these buffer solutions.

To test the possibility of using the spectrophotometry method in determining the concentration of quercetin solutions it was necessary to investigate the influence of auxiliary substances on the total spectrum of investigated solutions. To this end, we have studied the adsorption spectra of experimental solutions obtained at determining the solubility of the solid dispersions of quercetin in corresponding buffer solutions. 


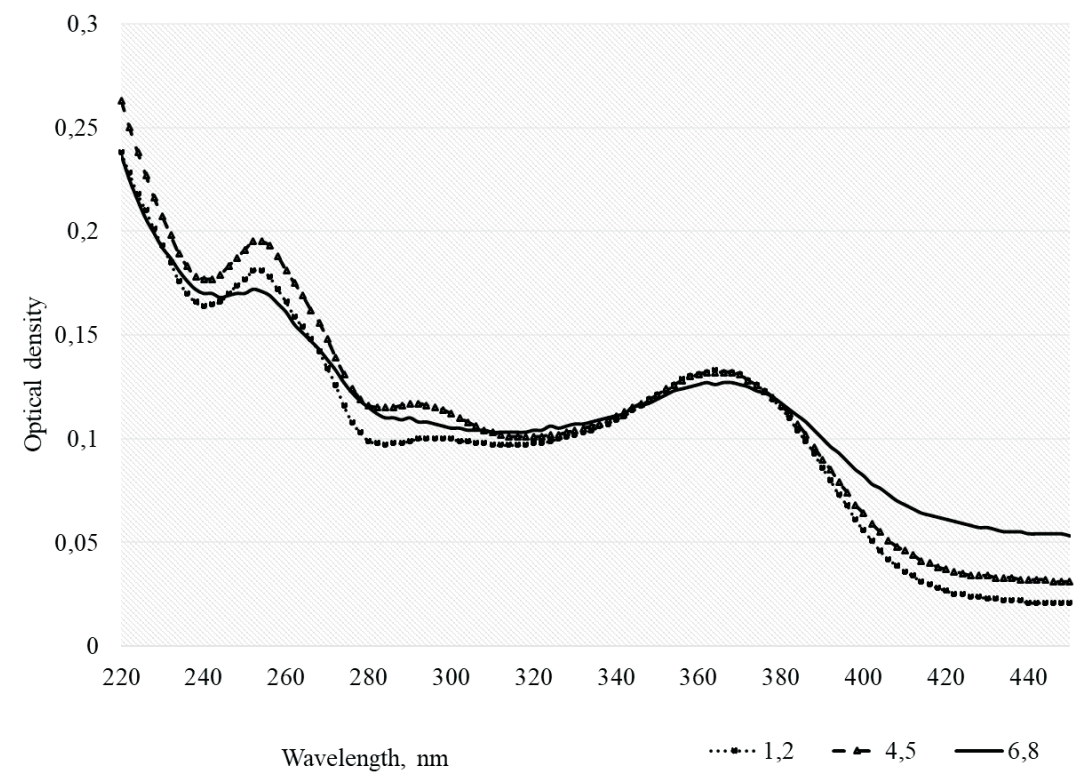

Fig. 2. The adsorption spectrum of the test solution of quercetin SS in buffer solutions with pH of 1.2; 4.5; 6.8

The adsorption spectra of quercetin solid dispersion solutions obtained in experiments in the range from 220 to $450 \mathrm{~nm}$ in character, location of absorption bands and their intensity are completely identical with the character, location and absorption intensity of the quercetin SS solutions in the corresponding buffer solution, which allows recognizing the band in the spectrum with a maximum at $365 \mathrm{~nm}$ as analytical and using it to determine the concentration of solutions by adsorption spectrophotometry (Fig. 3).

One of the main requirements that makes it possible to use spectral methods for quantification of a substance is the subordination of light absorption of its solutions to the Beer-Lambert Law. The verification of the subor- dination to the Beer-Lambert Law is reduced to plotting the dependence of the optical density (A) against the concentration of the solution. Absorption of solutions is subject to the Beer-Lambert Law only within the concentrations in which the calibration graph is a straight line. Within these limits, the absorption index $\chi$ calculated in the form of the specific absorption index should be the same.

The optical density of the resulting quercetin solutions was determined at a wavelength of $334 \mathrm{~nm}$. The obtained results are presented in Fig. 4 and Tab. 1.

Thus, the analysis of the experimental data shows that absorbance of quercetin solutions in a buffer solution with a pH of 1.2, 4.5 and 6.8 at a maximum at $365 \mathrm{~nm}$

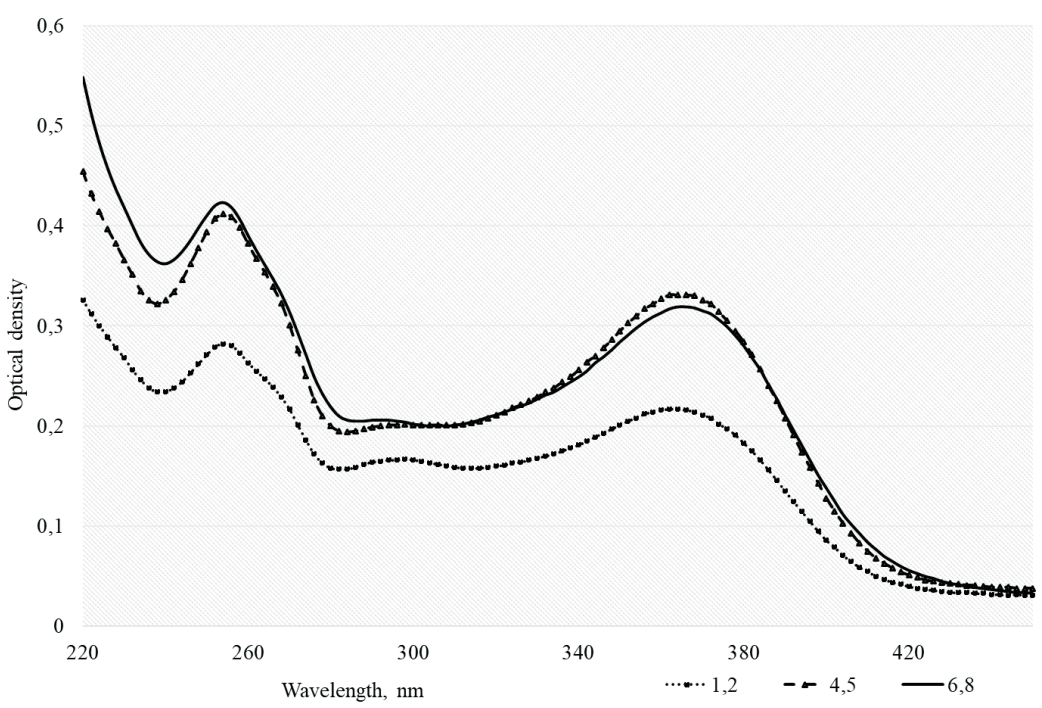

Fig. 3. Adsorption spectrum of solid dispersion solutions in buffer solutions with $p H$ 1,2; 4,5; 6,8 


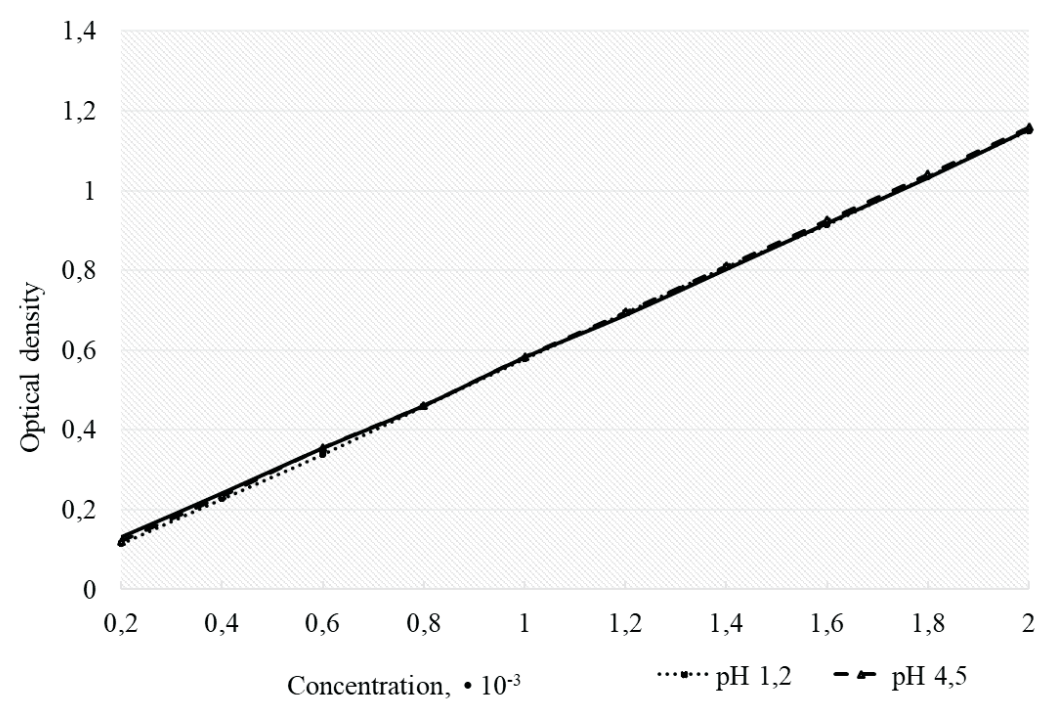

Fig. 4. Calibration graph of quercetin solutions optical density dependence on concentration in a buffer solution at $p H 1.2,4.5,6.8$

is linear and obeys Beer-Lambert Law in the entire range of investigated concentrations from 0.2 to $2.0 \times 10^{-3} \%$. Specific absorption index at the same time is $573 \pm 2.3$ (pH 1.2), $584 \pm 4,7$ (pH 4.7) and $580 \pm 5.6$ (pH 6.8).

The presence of a linear dependence between concentration and absorbance suggests the possibility of determining the concentration of quercetin solutions in buffer solutions with $\mathrm{pH}$ of 1.2, 4.5 and 6.8 by the method of one-wave direct spectrophotometry with the subsequent calculation of concentration by the standard method.

At the next stage of the work, the biopharmaceutical solubility of quercetin and its solid dispersion was determined, its rates in the minimum and maximum doses of $50 \mathrm{mg}$ and $1001 \mathrm{mg}$ were calculated with calculation of the dose value $\left(\mathrm{D}_{0} \min , \mathrm{D}_{0} \max \right)$ and the dose to solubility relation $\left(\mathrm{S}_{i} \min , \mathrm{S}_{\mathrm{i}} \max \right)$ (Tab.2).

As can be seen from the results presented in the table, the use of solid dispersions significantly increases the biopharmaceutical solubility rates compared to the native quercetin substance. Calculation of the dose value for $50 \mathrm{mg}$ and $100 \mathrm{mg}$ showed that the solubility increases equally proportionally. So in a buffer solution with $\mathrm{pH}$ 1.2 corresponding to the stomach environment, $\mathrm{D}_{0} \max$ decreases by almost 8 times, with a pH of 4.5 by 36 , with

Table 1

\section{THE OPTICAL DENSITY DEPENDING ON THE CONCENTRATION OF QUERCETIN AND THE PH OF THE BUFFER SOLUTION}

\begin{tabular}{|c|c|c|c|c|c|c|c|c|c|c|}
\hline & 1 & 2 & 3 & 4 & 5 & 6 & 7 & 8 & 9 & 10 \\
\hline \multicolumn{11}{|c|}{ pH 1,2 } \\
\hline A & 0.115 & 0.227 & 0.339 & 0.459 & 0.578 & 0.693 & 0.808 & 0.914 & 1.034 & 1.150 \\
\hline \multicolumn{11}{|c|}{ pH 4.5} \\
\hline$C \cdot 10^{-3}, \%$ & 0.2 & 0.4 & 0.6 & 0.8 & 1.0 & 1.2 & 1.4 & 1.6 & 1.8 & 2.0 \\
\hline A & 0.121 & 0.234 & 0.355 & 0.461 & 0.583 & 0.695 & 0.811 & 0.926 & 1.041 & 1.159 \\
\hline$C \cdot 10^{-3}, \%$ & 0.2 & 0.4 & 0.6 & 0.8 & 1.0 & 1.2 & 1.4 & 1.6 & 1.8 & 2.0 \\
\hline A & 0.132 & 0.242 & 0.355 & 0.461 & 0.582 & 0.688 & 0.803 & 0.918 & 1.032 & 1.153 \\
\hline$A_{1 \mathrm{sm}}^{1 \%}$ & 660 & 605 & 592 & 576 & 582 & 573 & 574 & 574 & 573 & 577 \\
\hline
\end{tabular}


INDICATORS OF THE BIOPHARMACEUTICAL SOLUBILITY OF QUERCETIN AND ITS SOLID DISPERSIONS

\begin{tabular}{|c|c|c|c|c|c|c|}
\hline Index & \multicolumn{3}{|c|}{$\mathrm{Q}$} & \multicolumn{3}{c|}{ SD Q } \\
\hline $\mathrm{pH}$ & 1.2 & 4.5 & 6.8 & 1.2 & 4.5 & 6.8 \\
\hline $\mathrm{D}_{0} \min$ & 57 & 40 & 104.17 & 5.21 & 1.09 & 3.85 \\
\hline $\mathrm{D}_{0} \max$ & 87.72 & 80 & 208.33 & 10.42 & 2.17 & 7.69 \\
\hline $\mathrm{S}_{i} \min$ & 17857.14 & 10000 & 26041.62 & 1302.08 & 271.74 & 543.48 \\
\hline $\mathrm{S}_{\mathrm{i}} \max$ & 43859.65 & 20000 & 52083.33 & 2604.17 & 961.54 & 1923.08 \\
\hline
\end{tabular}

a $\mathrm{pH}$ of 6.8 by 27 , for a dose of $50 \mathrm{mg}$ the dose value decreases in buffer solutions with a $\mathrm{pH}$ of 1.2 , by 10 times, with a $\mathrm{pH}$ of 4.5 by 40 , with a $\mathrm{pH}$ of 6.8 by 27 times. The dose value for $50 \mathrm{mg}$ is close to the norm (1) at dissolution of $\mathrm{SD}$ in a buffer solution of $\mathrm{pH}$ 4.5. The ratio of the therapeutic dose to the solubility also significantly decreases with the use of solid dispersions compared to the quercetin substance with the dependence, which was observed in the calculation of the dose value. The value of the ratio of the dose to the minimum solubility also reaches the norm for $50 \mathrm{mg}$ at $\mathrm{pH}$ 4.5. Thus, the use of solid dispersions significantly increases the value of biopharmaceutical solubility of quercetin in a dose of $100 \mathrm{mg}$, and at a dose of $50 \mathrm{mg}$ it is close to normal when using a $\mathrm{pH}$ of 4.5 .

\section{CONCLUSIONS}

1. In order to determine the possibility of developing a spectrophotometric method for determining the concentration of quercetin solutions for studying its biopharmaceutical solubility in dosage forms based on solid dispersions, adsorption spectra of its solutions in buffer solutions with pH 1.2; 4.5 and 6.8 have been studied. It was found that the adsorption spectra of quercetin solutions in the indicated buffer solutions contain a wide inclined absorption band at a maximum of $365 \mathrm{~nm}$, which can be used to determine quercetin solutions concentration using the one-component single-wave spectrophotometry method according to the standard.
2. It has been established that light absorption of quercetin solutions at $\lambda 365 \mathrm{~nm}$ is linear and obeys BeerLambert Law at $\mathrm{pH} 1.2$ in the concentration range from 2.50 to $11.25 \times 10^{-2} \%$ at $\mathrm{pH} 4.5$ in the range concentrations from 3.75 to $25.0 \cdot 10^{-2} \%$, at $\mathrm{pH} 6.8$ in the concentration range from 2.50 to $16.0 \cdot 10^{-2} \%$.

3. It has been proved that macrogol-6000, used in the preparation of solid dispersions, does not affect the adsorption spectrum of quercetin solutions in buffer solutions with $\mathrm{pH}$ of $1.2,4.5$, and 6.8 . The nature of the spectrum, location, and geometry of the maximum at $365 \mathrm{~nm}$ are unchanged, no additional bands or their geometry are observed. This indicates the correctness of determining the concentration of solutions by the method of direct one-component single-wave spectrophotometry with the calculation of concentration by the standard method.

4. The characteristics of quercetin and its solid dispersions biopharmaceutical solubility were studied. It has been established that according to the parameters of solubility in water buffer solutions with $\mathrm{pH}$ of $1.2,4.5$ and 6.8, quercetin refers to practically insoluble substances. Creation of solid dispersions allows increasing the solubility ratios from 8 to 40 times depending on the $\mathrm{pH}$ of the buffer solution. The maximum solubility value is observed at $\mathrm{pH}$ 4.5. The obtained results allow us to conclude that it is expedient to create entericsoluble coated medicines.

Conflict of interests: authors have no conflict of interest to declare.

\section{REFERENCES}

1. Bajaj, S. Antioxidants and diabetes/ S. Bajaj, A. Khan // Indian J. of Endocrinol. and Metabolism. - 2012. - Vol. 16. - P. 267-271.

2. Antioxidative activity of quercetin and quercetin monoglucosides in solution and phospholipid bilayers / K. Ioku, T. Tsushida, Y. Takei et al. // Biochim. Biophys. Acta. - 1995. - Vol. 1234. - P. 99-104. https://doi.org/10.1016/0005-2736(94)00262-n

3. Ковалевська, І. В. Визначення фізико-хімічних характеристик кверцетину / І. В. Ковалевська // Акт. питання фарм. і мед. практики. 2014. - № 1. - C. 9-11.

4. Kovalevska, I. Development of the methodological approach of obtaining preparations based on solid dispersions / I. Kovalevska, O. Ruban // ScienceRise: Pharm. Sci. - 2018. - № 4 (14). - P. 4-8. https://doi.org/10.15587/2519-4852.2018.140756

5. Study of physical and chemical properties of solid dispersions of quercetin / I. V. Kovalevska, E. A. Ruban, S. A. Kutsenko et al. // Asian J. of Pharmaceutics. - 2017. - Vol. 11 (4). - P. 805-809. https://doi.org/10.22377/ajp.v11i04.1719

6. Державна фармакопея України : в 3-х т. / Державне підприємство «Український науковий фармакопейний центр якості лікарських засобів». - 2-е вид. - Х. : Державне підприємство «Український науковий фармакопейний центр якості лікарських засобів», 2015. T. 1. $-1128 \mathrm{c}$

7. Биофармацевтическая классификация жизненно необходимых и важнейших лекарственных средств / Г. В. Раменская, А. Ю. Савченко, И. Е. Шохин и др. // Фармация. - 2011. - № 5. - С. 3-11.

8. Раменская, Г. В. Классификации лекарственных веществ по их биофармацевтическим свойствам - БКС и BDDCS / Г. В. Раменская, И. Е. Шохин, Ю. И. Кулинич // Вестн. ВГУ, серия: химия. биология. Фармация. - 2012. - № 1. - С. 213-215. 


\section{REFERENCES}

1. Bajaj, S., Khan. A. (2012). Antioxidants and diabetes. Indian Journal of Endocrinology and Metabolism, 16, 267-271.

2. Ioku, K., Tsushida, T., Takei, Y., Nakatani, N., \& Terao, J. (1995). Antioxidative activity of quercetin and quercetin monoglucosides in solution and phospholipid bilayers. Biochimica et Biophysica Acta (BBA) - Biomembranes, 1234 (1), 99-104. https://doi.org/10.1016/0005-2736(94)00262-n

3. Kovalevska, I. V. (2014). Aktualni pytannia farmatsevtychnoi i medychnoi praktyky, 1, 9-11.

4. Kovalevska, I., \& Ruban, O. (2018). Development of the methodological approach of obtaining preparations based on solid dispersions. ScienceRise: Pharmaceutical Science, 4 (14), 4-8. https://doi.org/10.15587/2519-4852.2018.140756

5. Kovalevska, I. V., Ruban, E. A., Kutsenko, S. A., Kutova, O. V., Kovalenko, S. V. (2017). Study of physical and chemical properties of solid dispersions of quercetin. Asian Journal of Pharmaceutics, 11 (4), 805-809. https://doi.org/10.22377/ajp.v11i04.1719

6. Derzhavna Farmakopeya Ukraïni: v 3 t. (2015). Derzhavne pidprimstvo “Ukraïns'kij naukovij farmakopejnij centr yakosti likars'kih zasobiv”. 2-e vid. - Kharkiv: Derzhavne pidprimstvo “Ukraïns'kij naukovij farmakopejnij centr yakosti likars'kih zasobiv”, 1, 1128.

7. Ramenskaia, G. V., Shokhin, I. E., Savchenko, A. Iu., Kulinich, Iu. I., \& Davydova, K. S. (2011). Farmatciia, 5, 3-11.

8. Ramenskaia, G. V., Shokhin, I. E., Kulinich, Iu. I. (2012). Vestn. VGU, seriia: khimiia. biologiia. Farmatciia, 1, 213-215.

\section{Information about authors:}

Kovalevska I., PhD, Associate Professor of the Department of Industrial Technology of Drugs, National University of Pharmacy.

E-mail: inga.kovalevskaya@gmail.com

Ruban O., Doctor of Pharmacy, Professor, Head of the Department of Industrial Technology of Drugs, National University of Pharmacy.

E-mail: ruban_elen@ukr.net. ORCID: http://orcid.org/0000-0002-2456-8210

Grudko V., PhD, Associate Professor of the Department of Pharmaceutical Chemistry, National University of Pharmacy

\section{Відомості про авторів:}

Ковалевська І. В., канд. фарм. наук, доцент кафедри заводської технології ліків, Національний фармацевтичний університет.

E-mail: inga.kovalevskaya@gmail.com

Рубан О. А., д-р фарм. наук, професор, завідувач кафедри заводської технології ліків, Національний фармацевтичний університет. E-mail: ruban_elen@ukr.net. ORCID: http://orcid.org/0000-0002-2456-8210

Грудько В. О., канд. фарм. наук, доцент кафедри фармацевтичної хімії, Національний фармацевтичний університет

Сведения об авторах:

Ковалевская И. В., канд. фарм. наук, доцент кафедры заводской технологии лекарств, Национальный фармацевтический университет.

E-mail: inga.kovalevskaya@gmail.com

Рубан Е. А., д-р фарм. наук, профессор, заведующая кафедрой заводской технологии лекарств, Национальный фармацевтический университет. E-mail: ruban_elen@ukr.net. ORCID: http://orcid.org/0000-0002-2456-8210

Грудько В. А., канд. фарм. наук, доцент кафедры фармацевтической химии, Национальный фармацевтический университет

Надійшла до редакції 31.01.2019 р. 